\title{
Evolution and changes in the physician-patient relationship
}

\author{
José Henry Osorio, PhD*
}

\section{SUMMARY}

The idealized vision of the physician-patient relationship was characterized by patient trust and physician availability, in a long-term relationship in which physicians knew many things about their patients and their families, being the physician a part of the patient's community. Physician employers, pharmaceutical companies, and insurance companies have abruptly entered the once private relationship between physicians and patients, changing a true relationship into a simple encounter. The substitution of the generic terms physician and patient for provider and client mirrors the increased impersonality of the encounter based on the commercialization of medicine. The present review analyzes the situations, which have led to the progressive and unavoidable deterioration of the physician-patient relationship within a globalized society.

\section{Keywords: Physician-patient relationship; Public access to information; Social change; Clients.}

Colomb Med. 2011; 42: 400-5

\section{Evolución y cambios en la relación médico-paciente}

\section{RESUMEN}

La visión idealizada de la relación médico paciente se caracterizó por la confianza del paciente y la disponibilidad del médico, en una relación de largo tiempo, en la cual el médico sabía muchas cosas de su paciente y su familia, siendo una parte de la comunidad del paciente. Los empleadores de los médicos, las compañías farmacéuticas y las compañías de seguros han irrumpido en la que una vez fue una relación privada entre médico y paciente, cambiando una verdadera relación por un simple encuentro. La sustitución de los términos genéricos de médico y paciente por los de proveedor y cliente, refleja la creciente impersonalidad del encuentro, basada en la comercialización de la medicina. La presente revisión, analiza las situaciones que han llevado al deterioro de la relación médico-paciente de manera progresiva e inevitable, en una sociedad globalizada.

Palabras clave: Relación médico-paciente; Acceso público a la información; Cambio social; Clientes.

Colomb Med. 2011; 42: 400-5

Throughout history, physicians have been socially respected not only for their knowledge, but fundamentally because of the attitudes they have assumed in society. In addition to their knowledge in medicine, physicians must also have sufficient foundation regarding the humanistic part of their congeners. Among the attitudes and medical skills, it is essential to consider, that in spite of any condition and circumstance the objective of reducing the suffering of others must prevail.

In ancient Egypt, the physician-patient relationship was subject to the decisions made by the clergy, who represented their patients before the gods, within a medical practice based on magic and mysticism, i.e., an active-passive model, respectively ${ }^{1}$. During the $5^{\text {th }}$ century before Christ, the Greeks developed an empirical-rational medical system, in keeping with the social changes of the young democracy. Because of this, the physician-patient relationship was based on cooperation between the physician and patient, to permit a judicious observation of the possible natural changes, likely responsible for the disease. The Hippocratic

* Research Laboratory on Clinical Biochemistry and Molecular Pathology, Department of Basic Sciences in Health, Universidad de Caldas, Manizales, Colombia. e-mail: jose.osorio_o@ucaldas.edu.co

Received for publication October 8, 2010 Accepted for publication February 7, 2011 
Oath traced a code of attitudes that physicians must assume in relation to their patients, making it clear that patients have rights and physicians must respond to their ethical obligations. It is an oath that embodies all humanity, when dealing with the needs, wellbeing, and interests of the patients, which sets it apart from other $\operatorname{codes}^{2}$. In medieval times with the imposition of religious ideas and superstition, there was a regression in the physician-patient relationship. Upon reviving the magical-religious beliefs, physicians were invested with magical powers and became superior in a society where patients were beings without hope within an activepassive model similar to ancient times ${ }^{3}$. The French Revolution, with the start of the Renaissance, gave way to Protestant movements with a permanent search for dignity, equality, and liberalism, opening new doors for medicine as an empirical science.

The system of guided cooperation was again imposed, changing the active-passive model imposed by the teachings of the Old Testament ${ }^{4}$. Since 1700 , the socalled «disease» model was adopted; the symptoms were equal to the illness and the patients were from the high aristocracy; hence, the patients were considered above the physicians and physicians had to compete amongst themselves to satisfy the patients. The medical approach dealt with each patient's individual signs and symptoms, which obligated physicians to be more interested in the needs and experiences of each patient, guaranteeing patient dominance ${ }^{5}$. With the surge of hospitals during the $18^{\text {th }}$ century, where patients without privileges were cared for, physicians interacted more with the patients who had been totally passive, but scientific progress, like microbiology and surgery, meant shift in medicine, aiming its attention to precision in the diagnosis of the pathological lesions inside the organism, also denominated «biomedical model of the disease» in which it was postulated that the symptom was not the illness, but an indicator of the presence or absence of such. This led patients being examined in depth by physicians experts in anatomy and clinical sciences to formulate the diagnosis, returning the patient in this case to being dependent on the physician within a passive attitude, arriving at the «paternalist» model of the physician-patient relationship, where the patient played the role of the child that had to be subjected to what the parentordered (active-passive) ${ }^{6}$. These models evolved during the 20th Century toward the model of «mutual participation» in which equality amongst humans (physicians and patients) brought advantages. Within this model, the physician did not manifest knowing exactly what was best for the patient, facilitating a process where both boasted equal power, mutual independence, and equal satisfaction, which permitted patients to care for themselves, as is the case in chronic disease. This model delegated onto the patient a higher degree of responsibility and it was characterized by a high degree of empathy in which the physician could feel real satisfaction for the service offered to humanity ${ }^{7}$.

The physician-patient relationship may be analyzed according to the degree of participation each has; such is the case where the physician assumes an active role and the patient assumes a passive role, in those cases in which patients are incapable of fending for themselves, as in medical or surgical emergencies. There is also the case where the physician directs and the patient cooperates, as in infectious and traumatic diseases among others; in these, the patient cooperates, thus, contributing with the treatment, under the direction of the physician. A third case is when there is equal participation between physicians and patients, as in the case of chronic disease in which the patients participate actively and may take the initiative in their treatment, under the instructions and supervision of the physician ${ }^{8}$.

According to the degree of personalization, three phases of the relationship are also observed. In the first phase, the physician tries to aid the patient when requested; in the second, the physician focuses on studying the process ailing the patient; and in the third, the physician draws the plan to be followed by establishing a relationship with the patient as such ${ }^{9}$.

According to the objective of the relationship, an interpersonal model can be identified where physicians interact affectively and intellectually with their patients in a broad sense. Likewise, there is the case in which the physician's attention is only directed towards the dysfunctional organ or system, with only the technical aspect being important for the physician; thereby, the patient is seen as a client. This is a model currently being imposed ${ }^{10}$. 


\section{CONDITIONS IN THE PHYSICIAN-PATIENT RELATIONSHIP}

It is hoped that physicians have two types of relational skills, namely: instrumental, or the conducts related to the task, and socio-emotional conduct. In the first, questions are made and information is provided; while in the latter, feelings are addressed and empathy and commitment are shown. Affective communication between physicians and their patients is characterized by a balance between instrumental conducts and affective conducts, depending on the patient's specific needs ${ }^{11}$. In recent times, a great deal of factors has been found impacting on the physician-patient communication. The most basic of these have to do with the physician's gender, given that with the increased number of women in the medical profession ${ }^{12}$, it has been found that women have their patients in mind when making decisions ${ }^{13}$, and they also bear in mind the psychosocial aspects involving their patients ${ }^{14}$. It has been proven that men are more likely to seek direct consultation, to use the medical jargon, and to focus more on physiciantype discussions ${ }^{15}$; while women like to talk more with their patients, obtaining better results and diminishing $\operatorname{costs}^{16}$. While males speak with a higher, stronger, tone of voice, dominating and competitive, interrupting others, communication from women is more emotional, subjective, and cordial, showing more commitment with the sentiments of others ${ }^{17}$; additionally, the verbal conducts of women are reflected in the non-verbal communication. There is evidence revealing that female medical professionals for the most part express and interpret emotions through non-verbal clues, more precisely than males ${ }^{14}$, for example through a smile ${ }^{18}$, although there are exceptions.

But gender is not the only aspect influencing the physician-patient relationship. It is clear that technological progress in medicine and telecommunications have notably influenced said relationship; thus, for example, the use of computers in the medical consultation drastically changed the physician's communication and personal treatment toward the patient. Using computers in the practice of general medicine began in the United Kingdom in 1972, and by 1982 there were 137 medical offices in the country with computers mediating in the medical practice ${ }^{19}$. This situation extended to developed nations and by 1993 in the
United Kingdom, 79\% of the medical consultation used computers. In 1997, it was calculated at $92 \%$, and currently $100 \%$ of the medical consultation has a computerized system and that tendency is making way in developing nations ${ }^{20}$. Using computers facilitates patient registration, relocations, screenings, repetition of prescriptions, and notations related with each case, as well as decisions on support aids, quick and opportune preventive measures, use of treatment protocols registered in the healthcare system ${ }^{21}$. Additionally, in some countries, physicians can enter the diagnosis and the computer suggests different standardized prescriptions, in the presence of the patient; also, recording the medical information in electronic files offers greater space than the traditionally used paper files ${ }^{22}$. But while the advantages of using computers in medical practice remain clear, it is also clear that this affects the physicianpatient relationship, proving that using this technology dehumanizes the relationship because physicians pay more attention to the computer than to the patient ${ }^{23}$, changing the so-called «conversation pattern with the patient» for one in which a series of data are permanently entered into the computer, depersonalizing patient care ${ }^{24}$. Besides, it is known that because of globalization of information, currently, patients are more informed each day about their health problems, which sometimes generates complications in the communication, given that having information available is not equal to having the criterion to understanding it, and the erroneous interpretations are numerous ${ }^{25}$.

It has been postulated that there are five fundamental factors influencing the relationship, namely: the increasing tendency for using ever-more sophisticated technologies to obtain the diagnostic certainty that permits improving the prognosis; the inter-consultation of patients with physicians specialized in clinical branches; the public healthcare system that has been progressively impoverishing; private healthcare systems that are perceived as medical businesses founded on exclusively economic motivations; and medical reductionism, based on the biologist conception of the disease $^{26}$. For other authors, the factors influencing on the physician-patient relationship are the appearance of a new morbidity, with predominance of chronic disease over acute disease; the appearance of sequelae of previously incurable disease; the indubitable determination of the health condition as a function of 
socio-environmental conditions; and the globalization of information that has narrowed the asymmetry of knowledge between patients and physicians ${ }^{27}$.

Physicians' employers, pharmaceutical companies, and insurance companies have entered the once private relationship: the physician-patient relationship ${ }^{28}$. This relationship has become a simple encounter rather than a relationship ${ }^{29}$. Substituting the generic terms of physician and patient for healthcare provider and client ${ }^{30}$, reflects the growing impersonality of the encounter and reveals the commercialization of medicine ${ }^{29}$. The idealized vision of this relationship characterized by the patient's trust and the availability of the physician was a long-term relationship in which physicians were aware of everything related to their patients and their families and were part of the patient's community ${ }^{31}$.

\section{EVOLUTION AND CHANGES IN THE PHYSICIAN-PATIENT RELATIONSHIP}

The initial conceptualization of the physician-patient relationship showed an ideal interaction, where physicians generated the best medical care they could give and their patients did everything that was recommended for their own good ${ }^{32}$. This conceptualization also received the cultural values, which physicians and patients contributed to the relationship and to the role played by the medical team and the patient's family ${ }^{33}$. In spite of the asymmetry in this relationship, the difference in the balance of power was not seen as an impediment in the quality of healthcare and the physician's authority was understood as a comprehensive part of the relationship, without considering that the physician could abuse of $\operatorname{such}^{34}$.

By the mid $20^{\text {th }}$ Century, the «paternalist metaphor» was coined for this relationship, given that it was similar to parent-child relationship where physicians assumed the parental figure in terms of obtaining the best interests for their patients, the child ${ }^{35}$. But during the 1970s, it was postulated that the relationship was beginning to change ${ }^{36}$. This was how the paternalist metaphor was replaced by the «cynical consumer metaphor», where the relationship simply became an encounter similar to a market transaction in which the degree of success or failure depends on economic benefit ${ }^{37,38}$. This metaphor was based on the palpable status gain by the patient, on the criticism against the power of physicians, which generated medical consumerism, where patients could challenge their physicians after acquiring the necessary knowledge to make decisions based on awareness concerning the therapeutic options $^{39}$. This position called by some the «client or patient revolution» is similar to the «revolution of the worker against the employer ${ }^{40,41}$.

Movements of frustrated consumers were organized, regarding patient care and the rights of patients and women's healthcare were enacted ${ }^{42,43}$. The courts took sides in the physician-patient relationship, guaranteeing the recognition of the rights and emphasizing on the obligations of physicians of providing relevant information ${ }^{39}$, the decisions of physicians began being influenced by the reactions, needs, and desires of the patients ${ }^{30}$ and decision making was no longer unilateral, profiling the embodiment of healthcare based on the conception of seeing the patient as a consumer ${ }^{44}$. After understanding healthcare as a commodity, healthcare could not break away from analysis of costs; thereby, needing executive experts in providing medical care. These administrators entered the «healthcare market» with high wages in detriment of the wages earned by physicians ${ }^{45,46}$, a situation denominated «deskilling of medicine» ${ }^{47,48}$, appearing then, the third metaphor or «corporatism metaphor» with which the $21^{\text {st }}$ century began, marked by the presence of healthcare intermediaries and the loss of physician and patient status, due to government abandonment of healthcare, which was placed in the hands of third parties ${ }^{49}$.

Above all, «corporatized» healthcare bears in mind the demands made by healthcare providing institutions (third parties), the health insurance companies and their users, which makes the third parties monitor the number of patients seen by the physician, as well as the time physicians dedicate to each patient, leading these administrators to scrutinize and manage the clinical decisions of the physicians ${ }^{50}$, which directly influences the physician-patient relationship. These third parties especially seek to save costs, offering incentives to physicians to limit patient remissions, placing physicians in the role of «doormen» who can determine who can see a specialist and who cannot, which can have negative repercussions in patient health ${ }^{51,52}$. All this enhances what was described in the 1960 s by Szasz $^{53}$ as the «double-agent metaphor», i.e., the double role the physician must play before the patient and before third 
parties. As if this were not enough -within a commercial savings strategy-administrators also expect physicians to work as experts in areas where they are not, given that they must often assume the leading roles in healthcare providing institutions in specific areas of medicine without even being specialists. All this gets complicated upon the possibility of the pharmaceutical companies selling medications to public without medical prescription, fusing self-diagnosis with self-medication as a base for self-care, without considering the physician in that process; something which is truly dangerous ${ }^{54}$.

\section{CONCLUSIONS}

The physician-patient relationship has historically evolved, often as a test of strength between both parts. Finally, and with the passage of time, it opts for the welfare of the patients, this being a mutual relationship where both have benefited. Mass information technologies have led to greater numbers of patients exercising self-diagnosis and to physicians being permanently questioned and even brought tojustice; this is detrimental for the trust physicians and patients once had on each other. Technological progress serving medicine has generated a more efficient medical practice, when trying to overcome disease, but it makes physicians perform in routine manner. Management of medical services by third parties, pressure from the pharmaceutical industry and medical insurance companies lead to the work of the physician to being questioned, intervened, limited, and poorly paid; all this bringing as a consequence a medical exercise that is conditioned to mercantilist forces, excessive savings, and increased revenues and profits for healthcare administrators. Because of the aforementioned, the physician-patient relationship has ruptured going on to be merely a moment in which physicians quickly gather and interpret data in impersonalized manner, without assigning the necessary importance to the humanist treatment and care patients should receive.

Conflict of interest. None of the authors has conflicts of interest related to this study.

\section{REFERENCES}

1. Edelstein L. A history of medicine. Arch Int Med. 1937; 5: 201.
2. Singer C. Hippocrates and the Hippocratic Collection. Vol.11. In: Encyclopedia Britannic. London; 2000. p. 583.

3. Schipperges H. La medicina en la Edad Media latina. Vol. 3. En: Entralgo L. (Ed). Historia universal de la medicina. Barcelona: Salvat; 1972. p. 181-241.

4. Szasz T, Hollender M. A contribution to the philosophy of medicine: the basic model of the doctor-patient relationship. Arch Int Med. 1956; 97: 585e92.

5. Jewson ND. The disappearance of the sick-man from medical cosmology, 1770-1870. Int J Epidemiol. 2009; 38: 622-33.

6. Shorter E. Doctors and their patients. A social history. New Brunswick: Transaction Publishers; 1991.

7. Balint M. The doctor, his patient and the illness. London: Pittman Medical; 1964.

8. Emanuel EJ, Emanuel LL. Cuatro modelos de la relación médico-paciente. En: Couceiro A. (ed). Bioética para clínicos. Madrid: Triacastela; 1999. p. 97.

9. Laín P. El médico y el enfermo. $2^{\text {a }}$ Ed. Madrid: Triacastela; 2003.

10. Siegler M. La relación médico-paciente en la era de la medicina de gestión. En: AA.VV. Limitación de prestaciones sanitarias. Madrid: Fundación Ciencias de la Salud/Doce Calles; 1997. p. 44-64.

11. Roter DL, Frankel R. Quantitative and qualitative approaches to the evaluation of the medical dialogue. Soc Sci Med. 1992; 34: 1097-103.

12. Denekens JP. The impact of feminization on general practice. Acta Clin Belg. 2002; 57: 5-10.

13. Elstad JI. Women's priorities regarding physician behavior and their preference for a female physician. Women Health. 1994; 21: 1-19.

14. Roter DL, Hall JA. Doctors talking with patients/patients talking with doctors. Improving communication in medical visits. 2nd Ed. London: Praeger; 2006.

15. Roter DL, Hall JA, Aoki Y. Physician gender effects in medical communication: a meta-analytic review. J Am Assoc. 2002; 288: 756-64.

16. Dacre J. Are there too many female medical graduates? No. $\mathrm{Br}$ Med J. 2008; 336: 748-9.

17. Aries E. Gender differences in interaction: A re-examination. In: Canary DJ, Dindia K, (eds). Sexdifferences and similarities in communication. New Jersey: Lawrence Erbaum Associates; 1998. p. 65-81.

18. Hall JA. How big are nonverbal sex differences? The case of smiling and sensitivity to nonverbal clues. In: Canary DJ, Dindia K, (eds). Sex differences and similarities in communication. New Jersey: Lawrence Erbaum Associates; 1998. p. 155-77.

19. Millman A, Lee N, Brooke A. The ABC of medical computing: computers in general practice. Br Medical J. 1995; 311: 8647.

21. Pringle M, Robins S, Brown G. Assessing the consultation: method for measuring changes in patient stress and arousal. $\mathrm{Br}$ Medical J. 1984; 288: 1657-8.

22. Barrows RC, Clayton PD. Privacy, confidentiality and electronic medical records. J Am Med Inform Assoc. 1996; 3 : 139-48. 
24. Reiffen B, Sherman H. The use of computers in ambulatory care: lessons from 3000 encounters. Comput Biol Med. 1973; 3: $101-5$.

25. Camp MC, Wong WW, Mussman JL, Gupta SC. The battle for hearts and minds: who is communicating most effectively with the cosmetic marketplace? Aesthet Surg J. 2010; 30: 614-7.

26. Sorokin P. Relación intersubjetiva médico-paciente: En defensa propia. Rev Latinoam Der Med Medic Leg. 2000; 5: 89-92.

27. Torres R. Las dimensiones éticas de la relación médicopaciente frente a los esquemas de aseguramiento. En: XIII Curso OPS/OMS-CIESS Legislación de Salud. La regulación de la práctica profesional en salud. México, DF, 4-8 de septiembre de 2006.

29. McKinlay JB. Bring the sociological back. In: Royal Holloway (Ed.). Studies of the provider-patient relationship: some problems with Bayesian reasoning. Continuity and change in health and medicine. London: University of London; 1999. p. 20-3.

28. McKinlay JB, Marceau LD. The end of the golden age of doctoring. Int J Health Serv. 2002; 32: 379-416.

30. Reeder LG. The patient-client as a consumer: some observations on the changing professional-client relationship. J Health Soc Behav. 1972; 13: 406-12.

31. Bellin LE. Shrinking autonomy of the practicing physician and its impact on quality. J Commun Health. 1986; 11: 15564.

32. Parsons T. The social system. New York: The Free Press; 1951.

33. Bloom SW. The doctor and his patient. New York: The Free Press; 1963.

34. Arrow KJ. Uncertainty and the welfare economics of medical care. Am Econom Rev. 1963; 53: 941-73.

35. Balint J, Shelton W. Regaining the initiative: forging a new model of the patient-physician relationship. J Am Med Assoc. 1996; 275: 887-91.

36. Campbell J. Working relationships between providers and consumers in a neighborhood health center. Am J Pub Health. 1971; 60: 97-103.

37. Beisecker AE, Beisecker TD. Using metaphors to characterize doctor-patient relationships: paternalism vs. consumerism. Health Commun. 1993; 5: 41-58.
38. Hamilton PA. Health care consumerism. St. Louis: MO Mosby; 1982.

39. Starr P. The social transformation of medicine. New York: Basic Books; 1982.

40. Haug MR, Sussman MB. Professional autonomy and the revolt of the client. Soc Problem. 1969; 17: 153-60.

41. Haug A, Lavin A. Consumerism in medicine: challenging physician authority. Beverly Hills: Sage Publications; 1983.

42. Rodwin MA. Patient accountability and quality of care: lessons from medical consumerism and the patients' rights, women's health and disability rights movement. Am J Law Med. 1994; 20: 147-74.

43. Schlesinger M. A loss of faith: the source of reduced political legitimacy for the American medical profession. Milbank $Q$. 2002; 80: 185-235.

44. Bodenheimer T. The industrial revolution in health care. Soc Just. 1995; 22: 26-42.

45. Waitzkin H, Iriart C, Estrada A, Lamadrid S. Social medicine then and now: Lessons from Latin America. Am J Public Health. 2001; 91: 1592-601.

46. Waitzkin H, Iriart C, Estrada A, Lamadrid S. Social medicine in Latin America: productivity and dangers facing the major national groups. Lancet. 2001; 358: 315-23.

48. Reed RR, Evans D. The deprofessionalization of medicine: causes, effects and responses. J Am Med Assoc. 1987; 258: 3279-82.

49. Ameringer CF. State medical boards and the politics of public protection. Baltimore: The John Hopkins University Press; 1999.

50. Waitzkin H. At the front lines of medicine. New York: Rowman \& Littlefield; 2001.

51. Kikano GE, Snyder CW, Callahan EJ, Goodwin MA, Stange KC. A comparison of ambulatory services for patients with managed care and fee-for-service insurance. Am J Manag Care. 2002; 8: 181-6.

52. St. Peter RF, Reed MC, Kemper P, Blumenthal D. Changes in the scope of care provided by primary care physicians. NEngl J Med. 1999; 341: 1980-5.

54. Petersen M. Increased spending on drugs is linked to more advertising. The New York Times, November 21, 2001: 1. 